\title{
REPLACING MAIZE WITH CASSAVA ROOT MEAL OR ITS MIXTURE WITH BREWERS YEAST SLURRY IN RABBIT DIETS
}

\author{
IKURIOR S.A. and AKEM J.D. \\ Department of Animal Production, University of Agriculture, Makurdi \\ Received 24 March 1997; Accepted 03 March 1998
}

\begin{abstract}
Three diets were evaluated for their effect on the performance, carcass yield and organ measurements of finisher rabbits. The control was maize-based (MC) while, in the other two diets, cassava root meal (CR) or its mixture with brewers yeast slurry (CYS) replaced the maize. Five approximately 9-week old crossbred (Chinchilla X California $X$ New Zealand White) rabbits which averaged $930 \mathrm{~g}$ liveweight, were allocated to each diet and fed individually for $\mathbf{7 0}$ days. The rabbits were then slaughtered and their dressed carcasses and organs weighed. At 70 days of feeding, the average liveweights of rabbits fed MC, CR and CYS were $2120 \mathrm{~g}, 2026 \mathrm{~g}$ and 2098 gespectively. Average daily feed intake, average daily gain and feed conversion ratio were $66.80 \mathrm{~g}, 64.92 \mathrm{~g}$ and $60.70 \mathrm{~g}, 15.65 \mathrm{~g}$ and $16.29 \mathrm{~g}$, and $3.92,4.15$ and 3.64 for the respective diets. Warm dressing \% and organ weights as percent of empty carcass weight did not differ significantly $(P>0.05)$ among the diets. Kidney fat weight was lower $(\mathrm{P}<0.05)$ for CYS than for MC and CR. Replacement of maize with $C R$ in the diet lowered $(P<0.05)$ rabbit performance, while that with CYS allowed for more efficient utilization of the diet, and for leaner carcasses of rabbits.
\end{abstract}

Key words: Cassava, brcwers yeast slurry, rabbits.

\section{INTRODUCTION}

In many of the less developed tropical regions, shortages in cereal grain supplies have persisted into the terminal years of the 20 th Century. Under such circumstance, the proportion of the grains usable in non-ruminant animal feeding dwindles, while feeding cost increases, in a corresponding persistent manner. Cassava products have for long been used as major energy sources, in place of cereal grains, for livestock (Khajaren et al., 1977; Walker, 1983). There is every likelihood of continued increasing use of cassava in animal feeding in the 21st Century and beyond. However due to low protein content in cassava root relative to that contained in maize grain, replacement of dietary maize with cassava usually results in wide protein deficits in such diets. Formulation of diets to eliminate the protein deficits requires incorporating higher quantities of good quality protein concentrates which are usually more expensive and scarce. While developing an inexpensive on-farm adaptable technology to preserve brewers yeast slurry (BYS), Ikurior, (1995) found that mixing cassava root meal with BYS at $1: 1$ ratio (w/w) resulted in an approximately $8 \%$ crude protein mixture. This associative enhancement of cassava root meal protein allowed its favourable comparison with maize grain on quantitative basis. The cassava root meal/BYS mixture was included in rations at the expense of maize grain and fed to growing (Ikurior et al., 1995), and growing-finishing (Ikurior and Achadu, 1995) pigs. In both studies this mixture effected, significantly, less costly, and somewhat better performance, of pigs; and their carcasses had the same characteristics as those fed the maize control diet.

This study was therefore planned to evaluate the effect of cassava root meal and cassava root meal/BYS mixture as maize replacers in the diets of finishing rabbits.

\section{MATERIALS AND METHODS}

\section{Preparation of Cassava Root Meal (CRM)}

Composite cassava roots were purchased from surrounding village farms. The fresh roots were cleaned of soil and other particles, and then chipped whole. The chips were 
TABle 1: "Proximate CHEMICAL COMPOSITION OF CRM, BYS AND THE SUN-DRIED MIXTURE OF BYS AND CRM

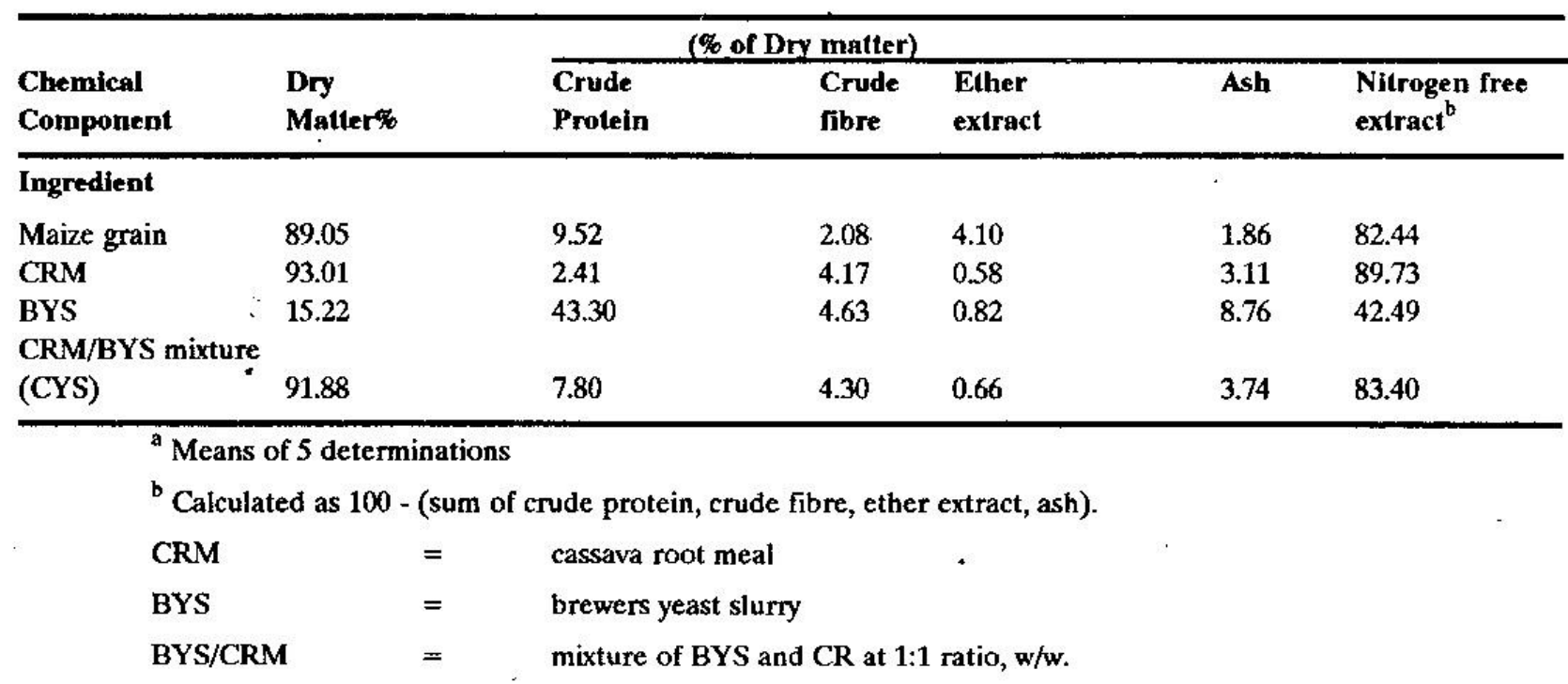

sun-dried on concrete slabs for 7 days after which they were milled and sampled for the determination of proximate chemical composition (Table 1) using A.O.A.C. (1984) methods. The material was stored in polythene bags prior to its use.

TABLE 2: PERCENTAGE COMPOSITION OF THE TEST DIETS

\begin{tabular}{llll}
\hline DIETS & MC & CR & CYS \\
\hline Ingredients & & & \\
Maize & 55.0 & - & - \\
Cassava root meal & - & 48.0 & - \\
CRM-BYS Mixture $^{\mathrm{a}}$ - & - & 55.0 & \\
Soyabean (full-fat) $_{\text {Brewers dried grain }}$ & 10.0 & 23.0 & 13.0 \\
Bone meal $_{\text {Sugar }}$ & 28.0 & 22.0 & 25.0 \\
Palm oil & 2.5 & 2.5 & 2.5 \\
Salt (NaCl) & 2.0 & 2.0 & 2.0 \\
Min-Vit-premix $^{\mathrm{b}}$ & 2.0 & 2.0 & 2.0 \\
Coccidiostat $^{c}$ & 0.5 & 0.5 & 0.5 \\
\hline
\end{tabular}

${ }^{3}$ Mixture, contained on dry basis, $84.32 \%$ cassava root meal, $15.68 \%$, brewers yeast slurry, $7.80 \% \mathrm{CP}$.

${ }^{\mathrm{b}}$ Containing per kg: 10,000,000IU Vit.A, 2,000,000IU Vit. D3, $0.75 \mathrm{~g}$ Vit. B1, 5.0g Vit.B2, 25g Nicotinic acid, $12.5 \mathrm{~g}$ Calcium pantothenate, $0.01 \mathrm{~g}$ Vit. $\mathrm{B}_{12}, 2.5 \mathrm{~g} \mathrm{Vit}, \mathrm{K}_{3}$, $25 \mathrm{~g}$ Vit. E, $0.05 \mathrm{~g}$ Biotin, $1 \mathrm{~g}$ Folic acid, $250 \mathrm{~g}$ Choline, $0.4 \mathrm{~g}$ Cobalt, $\mathrm{B}$ Copper, $32 \mathrm{~g}$ Iron, $0.8 \mathrm{~g}$ Iodine, $64 \mathrm{~g}$ Manganese, $40 \mathrm{~g}$ Zinc, $100 \mathrm{~g}$ Flavomycin, $5 \mathrm{~g}$ Spiramycin, $50 \mathrm{~g}$ DL-Methionine, $0.16 \mathrm{~g}$ Selenium, $120 \mathrm{~g} \mathrm{~L}$-Lysine, $5 \mathrm{~g}$ BHT. Inclusion rate $=1 \mathrm{~g} / \mathrm{kg}$ diet. cContaining $15 \mathrm{~g}$ Sulphoquinoxaline, $10 \mathrm{~g}$ nitrofurazone, and included at $1 \mathrm{~g} / \mathrm{kg}$ diet.

\section{Brewers Yeast Slurry Preservation}

Brewers yeast slurry (BYS) was obtained in two 40-1 plastic containers from Benue Brewery Ltd., Makurdi, and immediately sampled for chemical analysis. It was then mixed with CRM at $1: 1$ ratio $w / w$, and the misture sun-dried for about $\mathbf{4}$ days, to a moisture content of $10 \%$ or less. The dried material was sampled for proximate chemical composition (Table 1) using A.O.A.C. (1984) methods. It was stored in polythene bags until incorporated in the test diet.

\section{Experimental Diets}

Threc test diets were formulated such that all the maize grains contained in the control diet (MC) were replaced by either sole cassava root meal (CR) or its mixture with BYS (CYS). Full-fat soyabean which had been boiled for 45 minutes and sun-dried, provided the major protein which balanced each diet at approximately $16 \%$ crude protein. The percentage composition of the test diets is given in Table 2. The diets were fortified with a coccidiostat and min-vit premix. They were analysed for chemical composition according to A.O.A.C. (1984) methods, which, along with calculated values of some components, is presented in Table 3.

\section{Experimental Animals}

Growing-finishing crossbred (Chichilla X California X New Zealand White) rabbits 


\section{CASSAVA AND BREWERS YEAST SLURRY FOR RABBITS}

TABLE 3: CHEMICAL COMPOSITION OF THE TEST DIETS (\% DM, UNLESS OTHERWISE STATED).

\begin{tabular}{llll}
\hline DIETS & MC & CR & CYS \\
\hline PARAMETERS & & & \\
Dry matter & 89.10 & 91.33 & 90.82 \\
Crude protein & 16.88 & 16.37 & 16.75 \\
Crude fibre & 6.21 & 6.00 & 6.34 \\
Ether cxtract $_{\text {Ash }}$ & 8.09 & 7.47 & 6.98 \\
Nitrogen free extract $^{\mathrm{a}}$ & 4.00 & 4.51 & 6.50 \\
Calcium $^{\mathrm{b}}$ & 64.82 & 65.65 & 63.43 \\
Phosphorus (available) $^{\mathrm{b}}$ & 0.94 & 1.05 & 1.05 \\
Lysine $^{\mathrm{b}}$ & 0.58 & 0.59 & 0.60 \\
Methionine + Cystine $^{\mathrm{b}}$ & 0.71 & 0.88 & 0.99 \\
Metabolizable energy $^{\text {Mecal/kg) }}$ & 0.53 & 0.47 & 0.51 \\
(Kcal $^{\mathrm{b}}$ & & & \\
\hline
\end{tabular}

${ }^{\mathrm{a}}$ Nitrogen free extract $=100-($ sum of $\mathrm{CP}, \mathrm{CF}, \mathrm{EE}$, ash $)$.

${ }^{b}$ Calculated values based on Jurgens (1978) and

The Nutrient Master Plan. Nutrient Levels of Feed Ingredients by Pfizer Livestock Feeds Plc, Ikeja, Lagos.
Performance parameters were thus calculated. The experiment lasted 70 days by then all the rabbits had reached' at least $2000 \mathrm{~g}$ liveweight. The rabbits were then starved for $18 \mathrm{hr}$ and slaughtered by twisting their necks. They were skinned, eviscerated and decapitated prior to their empty body weights being recorded. The organs, liver, kidneys, hearts, lungs and trachea and empty stomach, were separated carefully and their fresh weights recorded, including kidney fat.

The data were analysed by the single-factor analysis of variạnce, and Duncan's Multiple Range Test was used to separate significant means, according to procedures described by Steel and Torrie (1980).

\section{RESULTS AND DISCUSSION}

Performance of the rabbits is summarized in Table 4. At 70 days, all rabbits fed the

TABLE 4: BREWERS' YEAST SLURRY AND CASSAVA ROOT MEAL IN DIETS OF FINISHING RABBITS. PERFORMANCE OF RABBITS.

\begin{tabular}{lllll}
\hline DIETS & MC & CK & CYS & SEM \\
\hline PARAMETERS & & & & \\
Number of rabbits & 5 & 5 & 5 & \\
Average initial liveweight (g) & 928 & 931 & 930 & $2098^{\mathrm{ab}}$ \\
Average final liveweights (g) & $2120^{\mathrm{a}}$ & $2026^{\mathrm{b}}$ & $60.70^{\mathrm{b}}$ & 3.44 \\
Daily feed consumption (g) & $66.80^{\mathrm{a}}$ & $64.92^{\mathrm{a}}$ & $16.69^{\mathrm{b}}$ & 0.92 \\
Daily gain (g) & $17.02^{\mathrm{a}}$ & $15.65^{\mathrm{b}}$ & $3.64^{\mathrm{b}}$ & 0.42 \\
Feed Conversion ratio & $3.92^{\mathrm{ab}}$ & $4.15^{\mathrm{a}}$ & & 0.25 \\
\hline
\end{tabular}

a,b means with different superscripts are significantly different $(P<0.05)$.

which were approximately 9 weeks old, were used in the experiment. The rabbits which averaged $930 \mathrm{~g}$ liveweight, were allocated in groups of five on the basis of liveweight, to each of the test diets. They were housed in hutches measuring $1 \times 0.6 \times 0.4 \mathrm{~m}(\mathrm{LxWxH})$ where they received their appropriate diet individually.

\section{Experimental Procedure}

The rabbits were weighed initially and weekly thereafter while on the experiment. They received weighed amounts of the diets daily and feed consumption was measured as the difference between the amount offered and the left-over portions weighed 24 hour later. Water was made available ad libitum. different test diets attained liveweights slightly above $2000 \mathrm{~g}$. Growth rate and terminal liveweights recorded for rabbits fed the maize-based control diet were significantly $(P<0.05)$ higher than those recorded for rabbits fed CR and, though they were also higher than those fed CYS diet, the differences were not significant $(\mathrm{P}>0.05)$. Daily consumption of CYS diet was less $(P<0.05)$ than that of both $\mathrm{CR}$ and MC. The bitter flavour of BYS has been said to be responsible for reduced voluntary intake of rations containing the material (Avila et al., 1985). The conversion of CYS diet was better $(\mathrm{P}<0.05)$ than that of CR. Ikurior et al., (1995) and Ikurior and Achadu, (1995) had 


\section{TABLE 5: BREWERS YEAST SLURRY AND CASSAVA ROOT MEAL IN DIETS OF FINISHING RABBITS. WARM DRESSING PERCENT AND ORGAN MEASUREMENTS.}

\begin{tabular}{lllll}
\hline \multicolumn{1}{c}{ DIETS } & MC & CR & CYS & SEM \\
\hline Parameter & & & & \\
Number of rabbits & 5 & 5 & 5 & \\
Warm dressing (\%) & 61.87 & 62.16 & 62.62 & $0.31 \mathrm{NS}$ \\
\%of empty carcass weight; & & & & \\
Kidney fat & 3.53 & 3.25 & 2.80 & $0.32 \mathrm{NS}$ \\
Liver & 2.83 & 2.95 & 2.80 & $0.15 \mathrm{NS}$ \\
Heart & 0.31 & 0.36 & 0.32 & $0.08 \mathrm{NS}$ \\
Lungs and trachea & 0.90 & 0.88 & 0.92 & $0.07 \mathrm{NS}$ \\
Kidneys & 0.67 & 0.66 & 0.69 & $0.06 \mathrm{NS}$ \\
Empty stomach & 1.01 & 1.08 & 0.98 & $0.11 \mathrm{NS}$ \\
Head & 10.55 & 9.8 & 11.00 & $0.38 \mathrm{NS}$ \\
Skin & 11.12 & 11.33 & 11.60 & $0.26 \mathrm{NS}$ \\
Feet & 2.30 & 2.46 & 2.40 & $0.15 \mathrm{NS}$ \\
\hline
\end{tabular}

NS $=$ Not significant $(\mathrm{P}>0.05)$.

similarly observed growing pigs to utilize diets containing CRM/BYS better than they did sole cassava root meal and maize - based diets. It is probable that a better balanced amino acid profile in CYS (Table 3) may have resulted in its enhanced utilization relative to the other two diets. Cassava as sole energy source, has been reported to reduce conversion efficiency of diets by non-ruminant animals (Oke, 1978) due to its high contents of ash and crude fibre (Muller et al., 1974). The performance of rabbits fed the three test diets in the present study was generally better than has been reported by other workers in the same global sub-region (Abu and Ekpenyong, 1993; Esonu and Udedibie, 1993).

The warm dressing percent of rabbits (Table 5) did not differ significantly $(P>0.05)$ among diets. Kidney fat as percent of empty carcass weight was significantly less $(P<0.05)$ for rabbits fed CYS than for those fed CR and MC. The kidney fat weight which also rclated directly with daily feed consumption, could be regarded as a measure of carcass fattiness (Ikurior and Achadu, (1995). Thus the sole cassava root meal diet (CR), which was least utilized, tended to result in fattier rabbit carcasses, since body fat deposition is a less efficient physiological process than lean tissuc deposition (Hammond et al., 1971). None of the organs was significantly affected $(P>0.05)$ by dietary treatment.

\section{SUMMARY AND CONCLUSION}

Replacement of dietary maize with sole cassava root meal resulted in lowered growth rate and feed efficiency of finisher rabbits; while that with BYS mixture resulted in better feed utilization. The wide protein content differential of maize $(9.5 \%)$ and cassava root meal $(2.4 \%)$ was substantially narrowed (7.8\%) by mixing the cassava root meal with BYS. Thus the economic value of utilizing BYS in rabbit feeding in the present study was that whereas replacing dietary maize with sole cassava root meal required $130 \%$ more soybean to equilize the protein content of the diets, the replacement with the mixture of CRM and BYS required only $30 \%$ more soyabean. Since BYS as an industrial waste product did not attract a market price (except transportation and preservation handling charges), its inclusion in the diet amounted to a reduced production cost input relative to maize and CRM. Where suitably located therefore, tropical rabbit producers could obtain enhanced production efficiency from feeding brewers yeast slurry mixture with cassava root meal.

\section{REFERENCES}

ABU O.A., and EKPENYONG T.E. (1993). Utilization of dried palm oil mill effluent by young growing rabbits. World Rabbit Sci. 


$$
\text { I(1). } 1 \dot{1}-15 .
$$

\section{CASSAVA AND BREWERS}

A.O.A.C., (1984). Official Methods of Analysis (14th edn). Association of Official Analytical Chemists, Washington D.C., U.S.A.

AVILA F.P. DelC., HERNANDEZS.A.L., and REYES G.A., (1985). Use of yeast culture in the feeding of pigs during fattening. Acta Agron, 35, 92 - 103.

ESONU B.O., and UDEDIBLE A.B.I., (1993). The effect of replacing maize with cassava peel meal on the performance of weaned rabbits. Nig. J. Anim. Prod. 20, 81 - 85.

HAMMOND, J. JR. MASON, I.L., and ROBINSON, T.J. (1971). Hammonds' Fam Animals, 4th ed., Edward Arnold, Londong, pp 136 - 138.

IKURIOR S.A., (1995). Preservation of brewers yeast slurry by a simple on-farm adaptable technology and its effect on performance of weaner pigs. Anim. Feed Sci. Technol. 53, 353 $-358$.

IKURIOR S.A., and ACHADU G.A., (1995). Replacement of maize with cassava root meal either alone or mixed with brewers yeast slurry in diets for growing-finishing pigs. Nig. J. Anim. Prod. 22 (2): 158 - 163.

IKURIOR S.A., KAANKUKA F.G., and DAVID S.I., (1995). Response of
YEAST SLURRY FOR RABBITS

weaner-grower pigs to diets containing sun-dried mixtures of brewers yeast slurry with maize grain and cassava root meal. Nig. J. Anim. Prod. 22 : (1) 56 - 63.

JURGENS, M.H. (1978). In: Animal Feeding and Nutrition (4th Edn) Dendall/Hunt Publishing Co., Dubuque, IA, U.S.A.

KHAJARERN S., KHAJARERN J.M., KITPANTNIK N. and MULLER Z.O., (1977). Cassava in the nutrition of swine. Cassava as Animal Feed. Eds Nestel B., Graham M. Proceedings of a workshop held at the University of Guelph, 18 - 20 April 1977 , OAtawa IDRC - 095e, 56 - 64.

MULLER Z., CHOU K.C., and NAH K.C., (1974). Cassava as a total substitute in livestock and poultry rations. World Anim. Rev. 12(1), 19 - 24.

OKE O.L., (1979). Problems in the use of cassava as animal feed. Anim. Feed Sci. Technol., 3: 345 - 380.

STEEL R.G.D., and TORRIE J.M., (1980). Principles and procedures of Statistics (2nd edn), McGraw-Hill Kogakusha.

WALKER N., (1983). Cereal replacers as alternative sources of energy for pigs. In, Heresign W. ed, Recent Advances in Animal Nutrition, Butterworth, London. 